\title{
Heliotropic responses of soybean cultivars at three phenological stages and under two water regimes
}

\author{
Miroslava Rakocevic ${ }^{(1)}$, Norman Neumaier(2), Gustavo Migliorini de Oliveira(3), Alexandre Lima Nepomuceno(2) \\ and José Renato Bouças Farias ${ }^{(2)}$
}

(1)Instituto Agronômico do Paraná, Caixa Postal 481, CEP 86047-902 Londrina, PR. E-mail: miroslava@iapar.br (2)Embrapa Soja, Caixa Postal 231, CEP 86001-970 Londrina, PR. E-mail: norman@cnpso.embrapa.br, nepo@cnpso.embrapa.br, jrenato@cnpso.embrapa.br(3)Universidade Estadual de Londrina, Departamento de Agronomia, Caixa Postal 6001, CEP 86055-900 Londrina, PR. E-mail: gmigliorini@hotmail.com

\begin{abstract}
The objectives of this work were to determine the heliotropic movements of the upper trifoliates for two soybean cultivars, BR 16 and Embrapa 48, during a daily cycle, in three phenological stages and two water regimes, and to estimate the impact of irrigation and daily leaflet movements on agronomic characteristics and grain yield. Heliotropic movements were studied in three phenological stages: V4-V6, V7-V10, and R5 in irrigated and non-irrigated plots. For each stage, the leaflet elevation and azimuth were measured hourly. Under a low (V4-V6 stage) and mid (V7-V10 stage) leaf area index (LAI) the diaheliotropism was slightly more frequent and intensive in non-irrigated than in irrigated plants, only at early morning and late afternoon hours. At R5 stage (high LAI) the paraheliotropism of superior trifoliates was predominant and more intensive in non-irrigated plants. The heliotropic movements are correlated to carbon gain, but not to environment (light intensity or temperature), for measurements at 11h. 'Embrapa 48' expresses greater paraheliotropism than 'BR 16' at high LAI, while 'BR 16' displays lower heliotropic plasticity under irrigation. In spite of significant heliotropic differences, genotype and water availability treatments did not influence the final grain yield.
\end{abstract}

Index terms: Glycine max, diaheliotropism, irrigation, leaf area index, paraheliotropism.

\section{Respostas heliotrópicas de cultivares de soja em três estádios fenológicos e dois regimes hídricos}

\begin{abstract}
Resumo - Os objetivos deste trabalho foram determinar o movimento heliotrópico dos trifólios superiores de duas cultivares de soja, BR 16 e Embrapa 48, durante o dia, em três estádios fenológicos e em dois regimes hídricos e determinar o impacto da irrigação e do movimento foliar diário nas características agronômicas e na produção de grãos. Movimentos heliotrópicos foram determinados a cada hora, em três estádios fenológicos: V4-V6, V7-V10 e R5, em parcelas irrigadas e não irrigadas. Para cada estágio, a elevação do folíolo e o azimute foram medidos por hora. Em índices de área foliar (IAF) baixo e médio (V4-V6 e V7-V10), o diaheliotropismo foi levemente mais intenso e frequente nas plantas sem irrigação do que nas irrigadas, e somente nas primeiras horas matinais e últimas horas da tarde. Em R5 (alto IAF), o paraheliotropismo dos trifólios superiores foi predominante e mais intenso em plantas não irrigadas. Os movimentos heliotrópicos se correlacionaram com o ganho de carbono mas não com o ambiente (intensidade de luz ou temperatura), para medidas às 11 horas. 'Embrapa 48' apresenta maior paraheliotropismo do que 'BR 16', em plantas com alto IAF enquanto 'BR 16' apresenta menor plasticidade nas respostas heliotrópicas nas parcelas irrigadas. Apesar de diferenças no heliotropismo, o genótipo e disponibilidade de água não influenciaram a produção de grãos.
\end{abstract}

Termos para indexação: Glycine max, cosseno, diaheliotropismo, irrigação, índice de área foliar, paraheliotropismo.

\section{Introduction}

The leaf area index (LAI) and the canopy leaf arrangement components, as inclination, azimuth, orientation and space distribution (Zheng et al., 2008), strongly affect the canopy light interception and photosynthesis (Ross et al., 2000).
Besides the changes of the inclination and azimuth through the plant canopy profile, some species also show complex daily heliotropic adjustments in leaf angles. The fast and reversible foliar and floral movements in response to changes in the position of the sun's direct beam were named heliotropism (Darwin, 1880). 
Darwin (1880) defined two types of heliotropic leaf movements, diaheliotropism and paraheliotropism. Diaheliotropism is the ability of leaves to track the sun, keeping leaf lamina perpendicular to the sun's direct rays. Its ecophysiological significance consists in the light interception maximization and the carbon gain enhancement, provided that the leaf has the physiological capacity to utilize high irradiances (Forseth \& Ehleringer, 1983). Paraheliotropism is the ability of leaves to maintain the leaf lamina parallel to the sun's direct rays, and this phenomenon is often associated with plant efforts to reduce the negative effects of water stress (Kao \& Forseth, 1992), UVB photoinhibition (Bawhey et al., 2003), and high leaf temperature (Bielenberg et al., 2003), generally acting on transpiration and stomatal conductance (Isoda \& Shah, 2006). Photosynthetic photon flux density (PPFD) (Fu \& Ehleringer, 1991), leaf temperature (Bielenberg et al., 2003), soil water potential, leaf water potential (Rosa et al., 1991), and nitrogen availability (Kao \& Forseth, 1992) also can affect leaf positioning.

The mechanism of heliotropic control is associated to turgor variations. The turgor alterations are activated through blue light receptors situated in the pulvinus in Fabaceae. Those "osmotic motors" are regulated by the endogenous biological clock and by light, perceived by phytochromes and, possibly, by phototropins (Moran, 2007).

Some differences in daily heliotropic movements were observed between soybean [Glycine max (L.) Merr.] cultivars by Rosa \& Forseth (1996). Various soybean physiological properties show fluctuations on a seasonal scale (Haskett et al., 2000), where drought stress is a major constraint to yield stability. The hypothesis is that daily heliotropic properties change during the soybean plant development, and that cultivars differentiated by the morphological and physiological properties would exhibit diverse heliotropic daily courses, and final grain production.

The objectives of this work were to determine heliotropic movements of the upper trifoliates for two soybean cultivars, BR 16 and Embrapa 48, during a daily cycle, in three phenological stages and two water regimes, and to estimate the impact of irrigation and daily leaflet movements on agronomic characteristics and grain yield.

\section{Materials and Methods}

The experiment was carried out at Embrapa Soja, Londrina $\left(23^{\circ} 11^{\prime} \mathrm{S}, 51^{\circ} 10^{\prime} \mathrm{W}, 612 \mathrm{~m}\right)$, Paraná state, Brazil, in a Latossolo Vermelho distroférrico (Santos et al., 2006) (Rhodic Hapludox). The soil was fertilized with $60 \mathrm{~kg} \mathrm{ha}^{-1}$ of $\mathrm{P}_{2} \mathrm{O}_{5}$ and $\mathrm{K}_{2} \mathrm{O}$.

The treatments consisted of two water regimes, irrigated (IRR) and non-irrigated (NI), as well as two cultivars, BR 16 and Embrapa 48, arranged in a complete block experimental design with split-plot arrangement and four replicates. The water regimes were applied in the main plots and cultivars in the split-plot. Both cultivars have the determinate growth type and semi-early maturity, i.e., number of main stem nodes being defined at flowering and life cycle of 125 days, respectively. However 'Embrapa 48' is considered more tolerant to drought than 'BR 16' (Oya et al., 2004).

Seeds were inoculated with Bradyrhizobium spp. just prior to sowing, on November 15, 2008. Each split-plot of $4 \times 5.5 \mathrm{~m}$ contained eight East-West soybean rows spaced $0.5 \mathrm{~m}$. Both water regimes received natural rainfall as it occurred. Soil humidity was monitored daily by tensiometers placed at $30 \mathrm{~cm}$ soil depth, and weekly by the gravimetric method and neutron probe. Irrigation was performed manually on the IRR plots using a hose with a predetermined flow rate. Duration of supplementary watering was controlled, keeping the soil water matrix potential between -0.03 and $-0.05 \mathrm{MPa}$. Irrigation with $13.2 \mathrm{~mm}$ was performed in 2008, on December 8, 22, 28, 29, 30; and with $11 \mathrm{~mm}$ on January 15, 2009.

All leaves at the main stem of ten plants in the two central rows of each split-plot, were labeled to facilitate leaflet position measurements. During the dates of leaflet measurements, data of air temperature $\left({ }^{\circ} \mathrm{C}\right)$ and rainfall $(\mathrm{mm})$ were collected hourly. Water balance (Thornthwaite \& Mather, 1955) was calculated (mm) for a period from pre-sown to soybean harvest (October, 2008 to April, 2009). Heliotropic movements were monitored in three phenological stages (dates): V4-V6 (December 17, 2008), V7-V10 (January 7, 2009), and R5 (February 3, 2009).

In each stage (date), leaf elevation and azimuth were measured hourly on the middle leaflet of the most recent, fully expanded leaf on each sampled plant. Leaflet position was defined by the cosine of the angle of incidence ( $\cos i)$, which is the cosine of the angle 
between the sun's direct beam and the leaflet lamina. It stands for the proportion of the direct beam incident on the leaflet. Therefore, cos $i$ of 1 describes a leaflet surface perpendicular to the direct beam, while a value of 0 represents a leaflet which is parallel to the direct solar beam.

The cos i was calculated according to the formula:

$$
\cos i=\cos \beta \times \cos z+\sin \beta \times \sin z \times \cos \left(a_{s}-a_{1}\right),
$$

where: $\beta$ is the leaflet angle from the horizontal; $z$, the solar zenith angle; $a_{s}$, the solar azimuth angle; and $a_{1}$, the leaf azimuth (Prichard \& Forseth, 1988). The solar angles were computed using the software VegeSTAR (Adam et al., 2006). The resulting daily sequence files contained solar angle data concerning each minute, obtained for each of the three observed dates, for the geographical coordinates of the field experiment. That information was used in cosine calculations.

Considering each of the three phenological stages described above, leaflet angles, from the horizontal and leaflet azimuth, were estimated from digital pictures taken at the field during a one-day-cycle. A couple of pictures of each leaflet were taken every hour, from $7 \mathrm{~h}$ to $20 \mathrm{~h}$ in Brazilian daylight saving time (13-14 cycles a day), adding up to 1.120 pictures taken per day. The first one was taken from "above" the field, using a camera pointing vertically down, to measure $\mathrm{a}_{\mathrm{l}}$, and the second one was taken "sideways" from South to North, using a camera pointing horizontally, to measure $\beta$. The leaflet angles registered in the pictures were determined in the laboratory, using free GIMP 2.6 software (GIMP, 2010) with tools for angle assessment.

In three phenological stages, leaf area index (LAI) was calculated as the leaf area measured on a leaf area meter LI-3100 (LICOR, Nebraska, USA) of five plants per split-plot, collected from a soybean row adjacent to the plants from where heliotropic measurements were taken, divided by the soil area occupied. Also, in the three phenological stages, leaf gas exchange (net photosynthesis, $\mathrm{A}, \mu \mathrm{mol} \mathrm{CO} \mathrm{C}^{-2} \mathrm{~s}^{-1}$ ), and stomatal

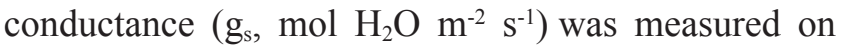
the upper trifoliate with a LI-6200 analyzer (LICOR, Nebraska, USA), when the diurnal assimilation was the highest (10h15-11h15). Simultaneously, the instantaneous values of photosynthetic photon flux density (PPFD, $\mu \mathrm{mol}$ photons $\mathrm{m}^{-2} \mathrm{~s}^{-1}$ ) and leaf temperature $\left(\mathrm{T}_{1},{ }^{\circ} \mathrm{C}\right)$ were registered. Agronomical characteristics, plant height in $\mathrm{cm}$, weight of stem and leaves, plant productivity, pod number, percentage of aborted pods and grain yield, were evaluated after harvest, March 25, 2009 for 'BR 16' and March 30, 2009 for 'Embrapa 48'.

The data normality was tested positive, and repetitive ANOVA(R) statistical analysis was used to test the significance of cultivar, treatments (IRR and NI) and hour in daily course associated to cosine. The statistical correlation between physiological and environmental parameters was evaluated by Pearson correlation analysis by regressing cos $\mathrm{i}, \mathrm{A}$ and $\mathrm{g}_{\mathrm{s}}$ upon the simple additive effects of microenvironment (PPFD and $\mathrm{T}_{1}$ ). Tukey test at $5 \%$ probability was applied to compare means of agronomical characteristics. For all analysis, the R statistical software (Venables \& Smith, 2010) was used. The results are presented graphically as means \pm standard errors.

\section{Results and Discussion}

The air temperatures in daily courses attained $29.2^{\circ} \mathrm{C}$ at $17-18 \mathrm{~h}(\mathrm{~V} 7-\mathrm{V} 10), 25.9^{\circ} \mathrm{C}$ at $17-18 \mathrm{~h}(\mathrm{R} 5)$, and high values were maintained until the end of daylight (Figure 1 A). During heliotropic daily measurements in V4-V6 stage, the highest temperature was recorded at $14-15 \mathrm{~h}\left(25.4^{\circ} \mathrm{C}\right)$, after which a quick rainfall decreased temperature until the end of daylight.

The water balance for soybean fields, adopting the $90 \mathrm{~cm}$ water storage depth, showed water excess during the most critical phases (January and February) for soybean production (Figure $1 \mathrm{~B}$ ). Water deficit occurred only in December.

The alterations in heliotropic movements, recorded through variation of the cosine during a daily course (Daylight time) were observed (Table 1). The cosine was also affected by irrigation and cultivar, and the multiple interactions between factors cultivar, irrigation treatment and daylight time were manifested. Those interactions showed the complex daily continuum between diaheliotropism and paraheliotropism (Rosa et al., 1991), differences in cultivar adjustment as well as adaptation to different water regimes.

The average LAI were $0.52-1.06$ for stage V4-V6; 2.59-4.72, for stage V7-V10; and 4.65-7.28, for stage R5. Figure 2 illustrates the cosine daily course registered for an early stage of development (V4-V6), with low crop LAI. Non irrigated plants (NI) 
of 'BR 16' gradually increased the intensity of diaheliotropic responses during the early morning (until 11h), while the irrigated ones (IRR) showed the diaheliotropism only at $11 \mathrm{~h}$ (Figure $2 \mathrm{~A}$ ). The daily course of 'BR 16' was characterized by paraheliotropic movements (until 16h). The second diaheliotropic response of IRR 'BR 16' was manifested at about $17 \mathrm{~h}$, and of the NI only at about $18 \mathrm{~h}$, both followed by a continuity of paraheliotropism until the end of daylight. The IRR 'Embrapa 48' showed one early morning (8h) and two afternoon (16h) occurrences of diaheliotropism, while the NI tracked the sun more frequently in early morning and afternoon hours (Figure 2 B). The average difference between IRR and NI plants in cos i was about 0.02 .

Under low leaf area index (LAI) on stage V4-V6, the IRR 'Embrapa 48' manifested the response described for soybean (Rosa et al., 1991), considering the expressions of diaheliotropism in the early morning and in the afternoon when ambient photosynthetic photon flux density (PPFD) and air temperature were lower, and paraheliotropism at noon, when PPFD and temperature were higher (Figure $1 \mathrm{~A}$ ). For this phenological stage, a strong negative correlation was established between carbon gain (A, leaf photossinthesis) and cosine in NI plants, while a positive correlation was shown in IRR ones (Table 2). No correlation between cosine and $T_{1}$
A

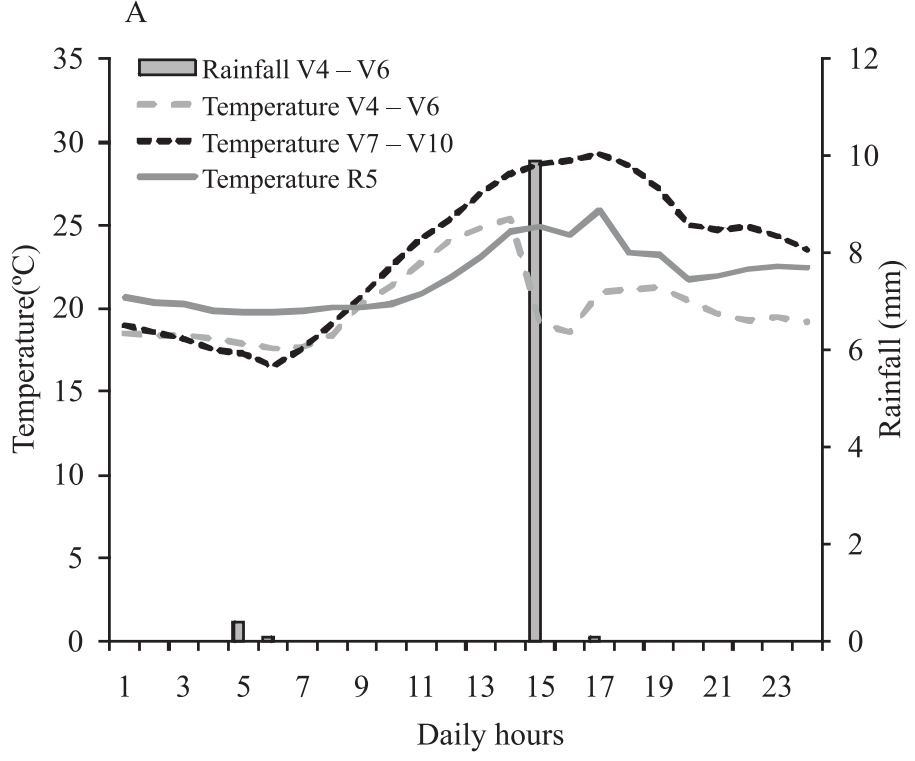

B

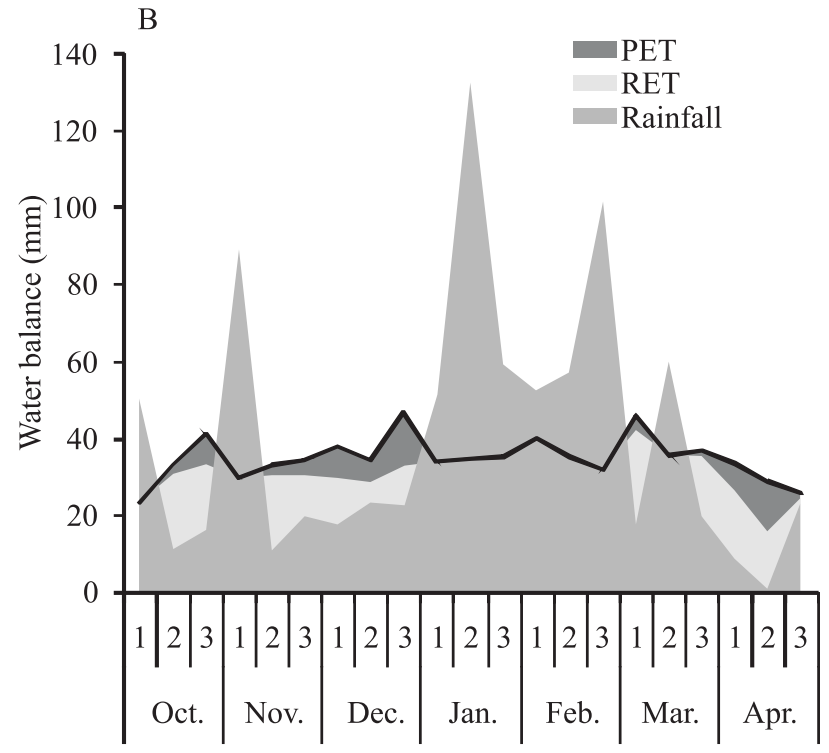

Figure 1. Meteorological data. A, daily courses of air temperature and rainfall corresponding to three dates of heliotropic measurements and plant phenological stages; B, Thornthwaite-Mather water balance for soybean bean fields, calculated every ten days period each month. PET, potential evapotranspiration; RET, real evapotranspiration.

Table 1. Analysis of variance for cosine of the angle of solar incidence for two soybean cultivars (BR 16 and Embrapa 48) grown under or without irrigation, and observed in three phenological stages (V4-V6, V7- 10 e R5) ${ }^{(1)}$.

\begin{tabular}{|c|c|c|c|c|c|c|}
\hline \multirow[t]{2}{*}{ Phenological stage } & \multicolumn{2}{|c|}{ V4-V6 } & \multicolumn{2}{|c|}{ V7-V10 } & \multicolumn{2}{|c|}{$\mathrm{R} 5$} \\
\hline & $\mathrm{F}$ & $\mathrm{p}$ & $\mathrm{F}$ & $\mathrm{p}$ & $\mathrm{F}$ & $\mathrm{p}$ \\
\hline Day light time (DLT) & 24.218 & $<0.0001$ & 46.303 & $<0.0001$ & 42.546 & $<0.0001$ \\
\hline Cultivar & 3.797 & 0.0519 & 42.724 & $<0.0001$ & 85.084 & $<0.0001$ \\
\hline Irrigation treatment & 27.000 & $<0.0001$ & 157.538 & $<0.0001$ & 63.199 & $<0.0001$ \\
\hline DLT x Cultivar & 35.872 & $<0.0001$ & 36.637 & $<0.0001$ & 20.532 & $<0.0001$ \\
\hline DLT $\mathrm{x}$ Irrigation treatment & 17.468 & $<0.0001$ & 98.091 & $<0.0001$ & 66.995 & $<0.0001$ \\
\hline Cultivar x Irrigation treatment & 3.086 & 0.0796 & 43.675 & $<0.0001$ & 85.303 & $<0.0001$ \\
\hline DLT x Cultivar x Irrigation treatment & 19.604 & $<0.0001$ & 24.744 & $<0.0001$ & 15.685 & $<0.0001$ \\
\hline
\end{tabular}

(1)ANOVA for hourly repetitive measures of cosine day light time. 
or PPFD was established for this early phenological, or other observed stages, indicating an internal mechanism of regulation, as a endogenous biological clock (Moran, 2007). The afternoon diaheliotropic response is probably related to the second peak in photosynthesis (Embrapa, 1997).

During V7-V10 stage and mid LAI, both cultivars showed long periods of diaheliotropism, intriguingly more in NI plants than in IRR ones (Figure 3).
Generally, leaflets maintained the diaheliotropic positions for longer periods in a daily course during this phenological stage compared to stage V4-V6 (Figure 2).

During V7-V10 stage, 'BR 16' manifested paraheliotropism in early morning (IRR), at noon (IRR and NI), and at the end of the day (IRR) (Figure $3 \mathrm{~A}$ ). Well synchronized diaheliotropic responses are observed between IRR and NI plants of 'BR 16', with
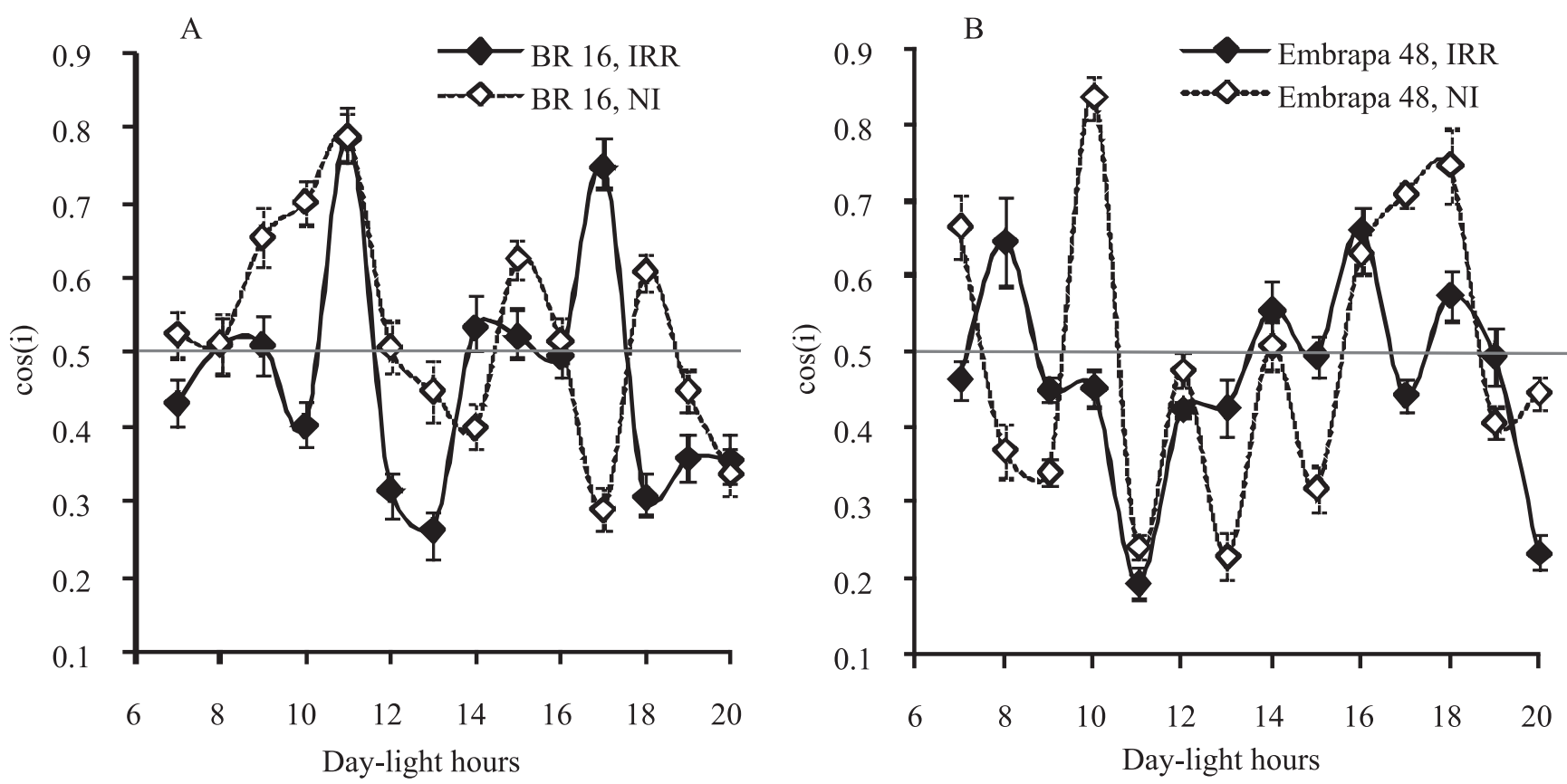

Figure 2. Diurnal courses of cosine of the angle of incidence $[(\cos (i)]$ of central leaflets in upper leaves of two soybean cultivars: 'BR 16' (A) and 'Embrapa 48' (B), grown under irrigation (IRR) and without irrigation (NI), measured for a stage V4-V6. The line for cosine $=0.5$, as a division between paraheliotropic and diaheliotropic responses, is indicated.

Table 2. Pearson correlation coefficient for the fitted values from the regression upon the simple additive effects of leaf temperature $\left(\mathrm{T}_{1}\right)$ and photosynthetic active radiation (PAR) of cosine of the angle of solar incidence [cos(i)] and photosynthetic photon flux density (PPFD), $\mathrm{T}_{1}$ and leaf gas exchange parameters (A, leaf photosynthesis; and $\mathrm{g}_{\mathrm{s}}$, stomatal conductance). All parameters were measured at midday for two soybean cultivars ('BR 16' and 'Embrapa 48') grown under irrigation (IRR) or without irrigation (NI), and observed in three phenological stages (V4-V6, V7- 10 and R5).

\begin{tabular}{|c|c|c|c|c|c|c|}
\hline \multirow[t]{3}{*}{ Variables } & \multicolumn{6}{|c|}{ Fitted cos (i) } \\
\hline & \multicolumn{2}{|c|}{ V4-V6 } & \multicolumn{2}{|c|}{ V7-V10 } & \multicolumn{2}{|c|}{ R5 } \\
\hline & IRR & NI & IRR & NI & IRR & NI \\
\hline$\overline{\mathrm{PPFD}}$ & $0.299^{\mathrm{ns}}$ & $-0.182^{\mathrm{ns}}$ & $0.282^{\mathrm{ns}}$ & $-0.374^{\mathrm{ns}}$ & $0.195^{\mathrm{ns}}$ & $0.109^{\mathrm{ns}}$ \\
\hline $\mathrm{Tl}$ & $0.540^{\mathrm{ns}}$ & $-0.139^{\mathrm{ns}}$ & $-0.362^{\mathrm{ns}}$ & $-0.371^{\mathrm{ns}}$ & $0.316^{\mathrm{ns}}$ & $-0.269^{\mathrm{ns}}$ \\
\hline A & $0.534 * * *$ & $-0.821 * * *$ & $0.269^{\mathrm{ns}}$ & $-0.332^{\mathrm{ns}}$ & $0.667 * *$ & $0.468 *$ \\
\hline gs & $-0.000^{\mathrm{ns}}$ & $-0.221^{\mathrm{ns}}$ & $-0.110^{\mathrm{ns}}$ & $-0.294^{\mathrm{ns}}$ & $-0.086^{\mathrm{ns}}$ & $0.334^{\mathrm{ns}}$ \\
\hline Fitted A & $0.650 * * *$ & $-0.986 * * *$ & $0.999 * * *$ & $-0.884 * * *$ & $0.719 * * *$ & $0.636^{* *}$ \\
\hline Fitted gs & $-0.010^{\text {ns }}$ & $0.022^{\mathrm{ns}}$ & $-0.451 *$ & $-0.407^{\mathrm{ns}}$ & $-0.475 *$ & $0.498 *$ \\
\hline
\end{tabular}

${ }^{\text {ns }}$ Not significant. *, ** and $* * *$ Significant at $5 \%, 1 \%$ and $0.1 \%$ of probability, respectively. 
one hour delay of the IRR ones. The IRR 'Embrapa 48' plants showed less frequent diaheliotropism compared to NI ones (Figure $3 \mathrm{~B}$ ), supporting the predominant paraheliotropic pattern, recorded earlier and extended longer into the afternoon, when observed in leaves of high water and high nitrogen supplied plants (Kao \& Forseth, 1992). At this stage, the cosine about $11 \mathrm{~h}$ was diaheliotropic and positively correlated to leaf photosynthesis in IRR plants, whatever negatively in NI ones (Table 2). In this daylight interval, the leaflet orientation did not differ between IRR and NI plants, but in the IRR ones it forced assimilation, while in NI, the photosynthesis was reduced, as stomatal conductance (negative correlation between cos i and $\mathrm{g}_{\mathrm{s}}$ ). Bunce (2005) observed the increased carbon gain during the most intensive diurnal assimilation period (about midday) in soybean grown under non-limiting water conditions and constant PPFD. The cotton cultivars comprising higher transpiring ability tend to have higher light interception per unit leaf area, showing active diaheliotropic leaf movement when grown under low water conditions (Wang et al., 2004), while Isoda \& Wang (2002) related the cotton leaf orientation to high transpiring ability supported by well developed root system.

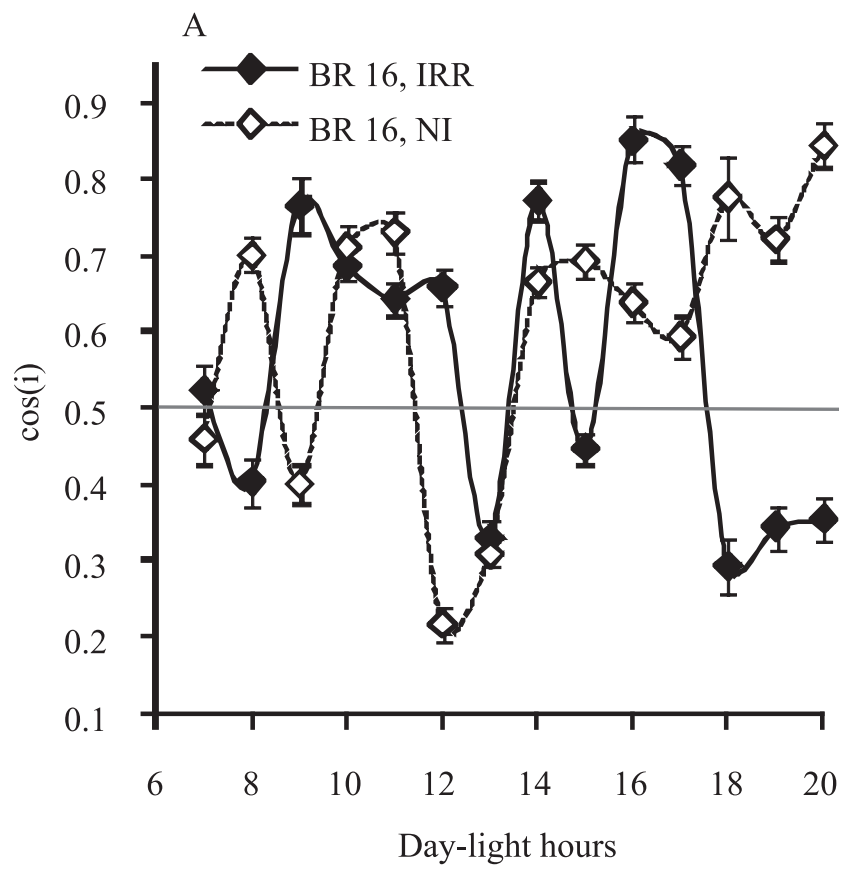

Direct solar beam avoidance (paraheliotropism) occurred in both cultivars and irrigation managements at noon in stage V7-V10 (Figure 3), in order to equilibrate photosynthetically active radiation absorption and water loss, as reported by Rosa \& Forseth (1996). Long diaheliotropic periods in a daily course, at stage V7-V10, indicate that this stage could be liable for the largest canopy carbon acquisition efforts compared to the total growth cycle.

The number of periods with diaheliotropic leaflet positions were drastically reduced for stage R5 compared to V7-V10, indicating that in final stages of development, soybean tends to position its upper leaves parallel to direct solar beams (Figure 4), because they may shade lower canopy leaves reducing their contribution for total plant carbon gain (Ehleringer \& Forseth, 1980). The diaheliotropic peaks were registered in the morning (through noon) and about $17 \mathrm{~h}$ in the afternoon, expressing lower intensity and duration compared to two previous phenological stages. IRR plants of 'BR 16' showed one morning period of four hours of diaheliotropism and the other one in the afternoon (about 17h), while the NI 'BR 16' pronounced only one midday peak (Figure 4 A), maintaining the prevailed paraheliotropic response, as

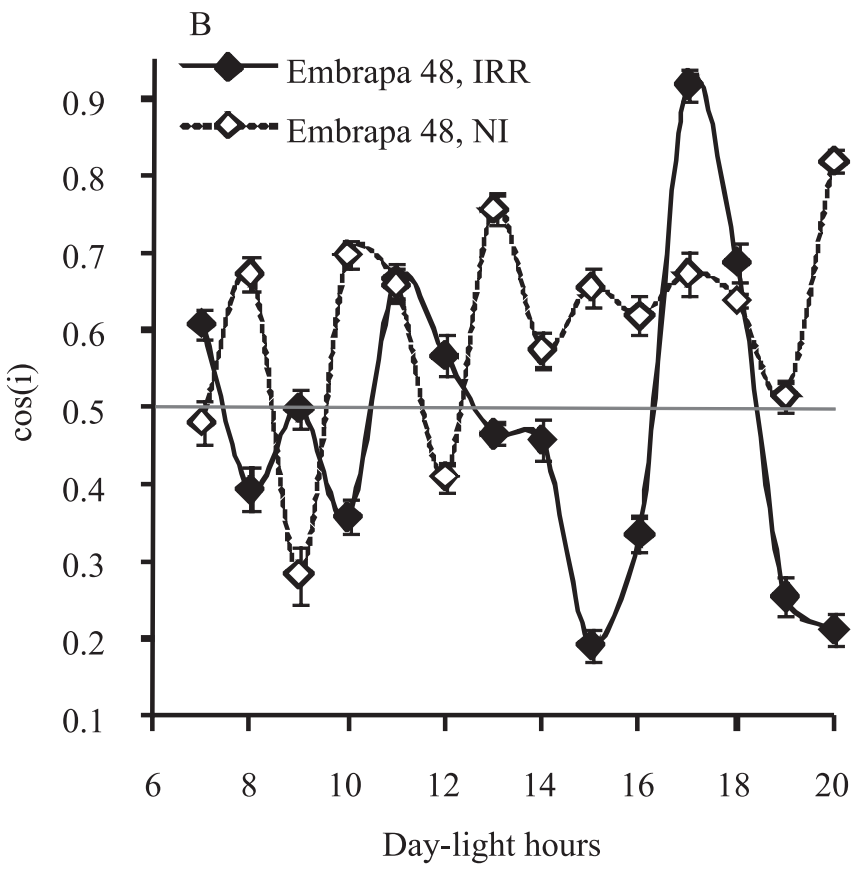

Figure 3. Diurnal courses of cosine of the angle of incidence [cos(i)] of central leaflets in upper leaves of two soybean cultivars: 'BR 16' (A) and 'Embrapa 48' (B), grown under irrigation (IRR) and without irrigation (NI) measured for a stage V7-V10. The line for cosine $=0.5$, as a division between paraheliotropic and diaheliotropic responses, is indicated. 
could be expected in soybean strategy in water deficit (Ehleringer \& Forseth, 1980). NI plants of 'Embrapa 48' showed one hour delay in the midday diaheliotropic response compared to IRR ones (Figure $4 \mathrm{~B}$ ), and one diaheliotropic response of low intensity at the end of the afternoon (about 19h).

In this stage, the positive correlation was established between the cos $i$ and leaf photosynthesis (about 11h), reducing the $g_{s}$ in IRR plants and increasing the $g_{s}$ in NI ones (Table 2), supporting the idea about the soybean adaptation in arid conditions by paraheliotropic movements and reduced transpiration (Isoda \& Wang, 2002).

In the initial stages, soybean intensively develop a leaf area through the intensive light interception and photosynthesis. Diaheliotropic reactions could increase the carbon gain in canopies of low LAI, whereas they could reduce the carbon gain in high LAI canopies (Ehleringer \& Forseth, 1980). To support this idea, the diaheliotropic movements seemed to promote the vegetative crop formation, from the stage of four to six green leaves to stage of flower formation (V7-V10). In a further plant and canopy development stage (R5), a strategy of photoassimilate translocation from leaves to reproductive organs prevails in the whole plant physiology. The transpiration was shown to be the main function affected by this strategy (Komor, 2000). In this sense, the paraheliotropic movements of the leaves from the upper layers in canopies with high LAI could play a role either in reducing transpiration, which results in a more efficient assimilate translocation to flowers, pods and grains, or in promoting better light distribution into the canopy.

The fresh and dry matter of stems and remaining leaves, number of pods and grain yield did not differed between the two cultivars (Table 3). The parameters that are related to the yield components, as number of pods, percentage of aborted pods and grain yield, have not been influenced neither by irrigation nor by genotype. Irrigation positively affected characteristics related to remnant vegetative structures and weight of vegetative organs. Between them, only plant height has been affected by the genotype interaction cultivar x irrigation. The IRR plants of 'Embrapa 48' were taller than all others, as well, NI plants of 'Embrapa 48 ', NI and IRR plants of 'BR 16'. This is related to water deficit observed only during a vegetative mass formation (Figure $1 \mathrm{~B}$ ) that could affect the plant size, but with no significant impact on grain yield. The coefficient of variation in calculated parameters attained high values
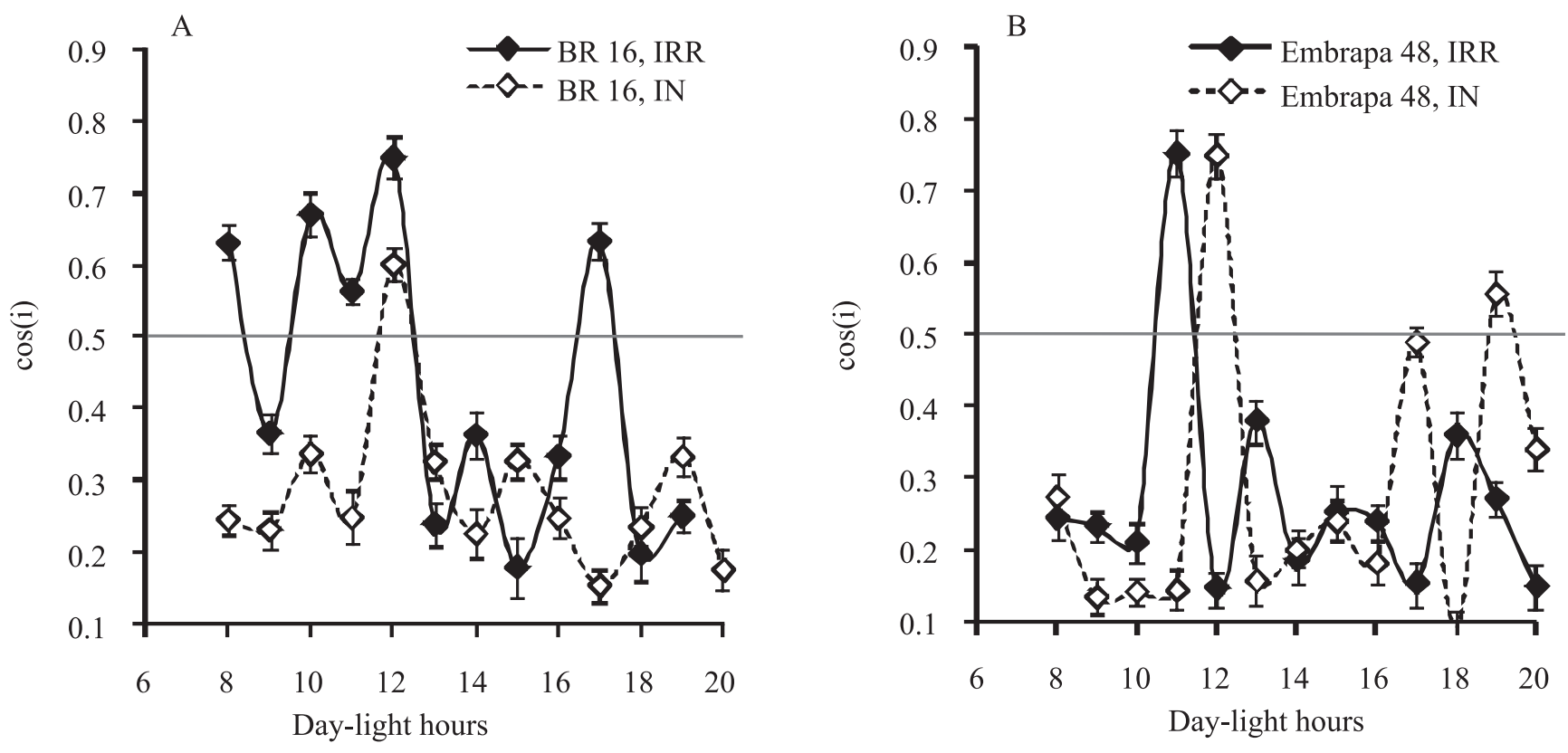

Figure 4. Diurnal courses of cosine of the angle of incidence [cos(i)] of central leaflets in upper leaves of two soybean cultivars: BR 16 (A) and Embrapa 48 (B), grown under irrigation (IRR) and without irrigation (NI) measured for a stage R5. The line for cosine $=0.5$, as a division between paraheliotropic and diaheliotropic responses, is indicated. 
due to a relatively small number of repetitions followed in order to minimally disturb the plant canopy (Table 2).

The plant height modification (Table 3) was well adjusted to its prevailed paraheliotropism in R5 (Figure 4), supporting better light distribution into the canopy. No differences in plant weight between the two cultivars indicate that the apical dominance was promoted in 'Embrapa 48' under irrigation, whereas 'BR 16' under the same conditions probably reacted with more intensive investment in branching or leaf formation or leaf conservation. Crop management, such as irrigation and plant density, can change the demands of population arrangement, therefore altering the plant structure. For example, the height of first fertile node increased as plant population increased and as soybean maturity lengthened (Edwards \& Purcell, 2005). In this sense, water deficit about the stages V2-V8 imposes a negative effect on plant height and weight of vegetative organs, probably as a consequence of complex interaction between the paraheliotropic reaction and carbon gain reduction.

Leaf angles were correlated with stomatal conductance and photosynthetic rate in soybean (Rosa et al., 1991). Moreover, the paraheliotropic soybean leaf movement and stomatal closure acted in parallel, beginning at approximately $-0.4 \mathrm{MPa}$ (Berg \& Heuchelin, 1990). On the other hand, even under constant environmental conditions the daily oscillations of many physiological processes were observed, as in photosynthesis (Dodd et al., 2005), or in stomatal opening and assimilation rate (Mencuccini et al., 2000).

Thus, characteristics responsible for creating oscillations had a component that varied throughout the day. The responses of controlling processes represent a complex interaction with environmental daily variations. It was shown that a substantial photosynthetic advantage is conferred by correct matching of the circadian clock period with that of the externallight-dark cycle in Arabidopsis thaliana (Dodd et al., 2005). The wild-types of this species, with a clock period matched to the environments, contain more chlorophyll, fix more carbon, grow faster, and survive better than plants with circadian periods differing from their environment. In the surveyed soybean cultivars, internal regulation mechanisms have an impact on leaflet movement control; however such regulation is not synchronized with the environment.

Grain yield did not suffer significant impacts, neither by the lack of irrigation, nor by genotype differences, nor by the daily course of adjustments in leaflet positions (Table 1). Water deficits during flowering, pod formation or grain filling usually decrease yields (Pires et al., 2005), however, considering the lack of water deficit in those stages (Figure 1 B), NI conditions were not harsh enough to cause significant impacts on yield. From a genetic point of view, the yield is a highly quantitative trait with low heritability, and influenced by differences arising from soil heterogeneity and environmental factors (Manavalan et al., 2009). That means soybean final grain production would be significantly affected by accumulated seasonal events than fine daily variations.

In spite of differences in heliotropic responses, the two cultivars showed similar grain yield. To better understand this final result, it would be necessary to conduct further detailed analyses of architectural and physiological parameters acting together with leaflet angle adjustments on grain yield and its quality. Recently, it was observed that the variation in amounts of blue, red and far red light (acting in photomorphogenesis) reflected to developing speckled Phaseolus lunatus plants and can alter physiological processes enough to affect seed yield,

Table 3. Agronomical characteristics evaluated after harvest of two soybean cultivars (BR 16 and Embrapa 48), grown under two water managements (irrigated, IRR; and non-irrigated, NI) ${ }^{(1)}$.

\begin{tabular}{|c|c|c|c|c|c|c|c|c|c|c|c|c|c|c|c|}
\hline \multirow{2}{*}{$\begin{array}{l}\text { Factors } \\
\text { Cultivar }\end{array}$} & \multicolumn{2}{|c|}{ Height $(\mathrm{cm})$} & \multicolumn{2}{|c|}{ Fresh weight (g) } & \multicolumn{2}{|c|}{ Dry matter (g) } & \multicolumn{2}{|c|}{ Pod number } & \multicolumn{4}{|c|}{ Aborted pods (\%) Grain yield $\left(\mathrm{kg} \mathrm{ha}^{-1}\right)$} & \multicolumn{3}{|c|}{$\begin{array}{l}\text { Interactions for height } \\
\text { (cultivar x irrigation) }\end{array}$} \\
\hline & BR 16 & E.48 & BR 16 & E.48 & BR 16 & E.48 & BR 16 & E.48 & BR 16 & E.48 & BR 16 & E.48 & & $\mathrm{NI}$ & IRR \\
\hline & $68.2 \mathrm{a}$ & $70.05 a$ & $22.46 \mathrm{a}$ & $19.97 \mathrm{a}$ & $5.88 \mathrm{a}$ & $5.02 \mathrm{a}$ & $35.75 a$ & $37.89 a$ & $13.53 \mathrm{a}$ & $7.21 \mathrm{~b}$ & $4018.08 \mathrm{a}$ & $4123.53 a$ & BR 16 & $62.70 \mathrm{Ab}$ & $73.70 \mathrm{Ba}$ \\
\hline \multirow[t]{2}{*}{ Irrigation } & $\mathrm{NI}$ & IRR & NI & IRR & NI & IRR & NI & IRR & NI & IRR & NI & IRR & E.48 & $57.00 \mathrm{Ab}$ & $80.80 \mathrm{Aa}$ \\
\hline & $59.85 \mathrm{~b}$ & $77.25 \mathrm{a}$ & $18.2 b$ & $24.12 \mathrm{a}$ & $4.29 b$ & $6.51 \mathrm{a}$ & $34.50 \mathrm{a}$ & $38.80 \mathrm{a}$ & $11.08 \mathrm{a}$ & $9.63 a$ & $3609.04 a$ & $4477.02 \mathrm{a}$ & & & \\
\hline CV (\%) & \multicolumn{2}{|c|}{8.81} & \multicolumn{2}{|c|}{39.63} & \multicolumn{2}{|c|}{33.87} & \multicolumn{2}{|c|}{39.36} & \multicolumn{2}{|c|}{38.66} & \multicolumn{2}{|c|}{40.93} & & & \\
\hline
\end{tabular}

${ }^{(1)}$ Means followed by the same letters, capital in a column and small in a line, do not differ by Tukey's test at $5 \%$ of probability. E. $48=$ Embrapa 48 . 
anthocyanin-containing area on seed coats, and amount of seed protein per plant (Kasperbauer \& Loughrin, 2004).

Heliotropic movements have had some practical agronomical applications, as the use of soybean leaflet angle data for scheduling irrigation (Wright \& Berliner, 1986). The most recent studies of these phenomena are related to plant-environment interface in $3 \mathrm{D}$, as conducted in simulations of soybean mitigation of UVB effects (Bawhey et al., 2003) and sunflower daily movements (Rey et al., 2008). The angular parameters obtained in this study could be applied in functional genotype comparisons, using 3D simulations for light interception and photosynthesis in diurnal courses, to estimate the carbon accumulation for the entire growing season, by the use of structural-functional models.

\section{Conclusions}

1. 'Embrapa 48' shows higher daily paraheliotropic leaflet activity than 'BR 16' at R5 stage.

2. In V4-V6 and V7-V10 stages, the diaheliotropism occurs even in midday in a daily course, but in V7-V10 stage leaflets maintain the diaheliotropic position for longer periods compared to V4-V6 stage, more in non-irrigated plants than in irrigated ones, promoting carbon gain.

3. Under irrigation, 'BR 16' displays lower heliotropic plasticity and plant height than 'Embrapa 48'.

4. The heliotropic movements of soybeans plants are correlated to carbon gain, but not to environment (light intensity or temperature) for measurements at $11 \mathrm{~h}$.

5. In spite of significant heliotropic differences, genotype and water availability treatments do not influence the final soybean grain yield, in growing seasons with well distributed rainfalls.

\section{Acknowledgements}

To Claudinei de Freitas Toledo and Nelson Delattre from Embrapa Soja and Ricardo Cláudio de Moura from IAPAR; to Fundação Araucária, for the financial assistance .

\section{References}

ADAM, B.; DONES, N.; SINOQUET, H. VegeSTAR: software qui calcule l'interception lumineuse et la photosynthèse. Version 3.2. Clermont-Ferrand: INRA, 2006. Available at: <http://www2. clermont.inra.fr/piaf/eng/download/download.php>. Accessed on: 28 Apr. 2010

BAWHEY, C.; GRANT, R.H.; GAO, W. Digital measurement of heliotropic leaf response in soybean cultivars and leaf exposure to solar UVB radiation. Agricultural and Forest Meteorology, v.120, p.161-175, 2003.

BERG, V.S.; HEUCHELIN, S. Leaf orientation of soybean seedlings. I. Effect of water potential and photosynthetic photon flux density on paraheliotropism. Crop Science, v.30, p.631-638, 1990.

BIELENBERG, D.G.; MILLER, J.D.; BERG, V.S. Paraheliotropism in two Phaseolus species: combined effects of photon flux density and pulvinus temperature, and consequences for leaf gas exchange. Environmental and Experimental Botany, v.49, p.95-105, 2003.

BUNCE J.A. Response of respiration of soybean leaves grown at ambient and elevated carbon dioxide concentrations to day-to-day variation in light and temperature under field conditions. Annals of Botany, v.95, p.1059-1066, 2005.

DARWIN, C. The power of movement in plants. London: William Clowes and Sons, 1880. 490p.

DODD, A.N.; SALATHIA, N.; HALL, A.; KÉVEI, E.; TÓTH, R.; NAGY, F.; HIBBERD, J.M.; MILLAR, A.J.; WEBB, A.A.R. Plant circadian clocks increase photosynthesis, growth, survival, and competitive advantage. Science, v.309, p.630-633, 2005.

EDWARDS, J.T.; PURCELL, L.C. Soybean yield and biomass responses to increasing plant population among diverse maturity groups: I. Agronomic characteristics. Crop Science, v.45, p.1770-1777, 2005.

EHLERINGER, J.; FORSETH, I. Solar tracking by plants. Science, v.210, p.1094-1098, 1980.

EMBRAPA. Centro Nacional de Pesquisa de Soja. Resultados de pesquisa da Embrapa-Soja 1993/1995. Londrina: Embrapa Soja, 1997. 193p. (Embrapa-CNPSO. Documentos, 100).

FORSETH, I.N.; EHLERINGER J.R. Ecophysiology of two solar tracking desert winter annuals. IV. Effects of leaf orientation on calculated daily carbon and water use efficiency. Oecologia, v.58, p.10-18, 1983.

FU, Q.A.; EHLERINGER, J.R. Modification of paraheliotropic leaf movement in Phaseolus vulgaris by photon flux density. Plant, Cell and Environment, v.14, p.339-343, 1991.

GIMP. GNU Image Manipulation Program. Version 2.6. Available at: <http://docs.gimp.org/2.6/en/>. Accessed on: 21 July 2010.

HASKETT, J.D.; PACHEPSKY, Y.A.; ACOCK, B. Effect of climate and atmospheric change on soybean water stress: a study of Iowa. Ecological Modelling, v.135, p.265-277, 2000.

ISODA, I.A.; SHAH, N.H. Adaptive responses of soybean and cotton to diurnal changes in solar radiation and leaf movement. Asian Journal of Plant Sciences, v.5, p.1007-1011, 2006.

ISODA, A.; WANG, P. Leaf temperature and transpiration of field grown cotton and soybean under arid and humid conditions. Plant Production Science, v.5, p.224-228, 2002.

KAO, W.Y; FORSETH, I.N. Diurnal leaf movement, chlorophyll fluorescence and carbon assimilation in soybean grown under 
different nitrogen and water availabilities. Plant, Cell and Environment, v.15, p.703-710, 1992.

KASPERBAUER, M.J.; LOUGHRIN, J.H. Butterbean seed yield, color, and protein content are affected by photomorphogenesis. Crop Science, v.44, p.2123-2126, 2004.

KOMOR, E. Source physiology and assimilate transport: the interaction of sucrose metabolism, starch storage and phloem export in source leaves and the effects on sugar status in phloem. Australian Journal of Plant Physiology, v.27, p.497-505, 2000.

MANAVALAN, L.P.; GUTTIKONDA, S.K.; TRAN, L.-S.P.; NGUYEN, H.T. Physiological and molecular approaches to improve drought resistance in soybean. Plant and Cell Physiology, v.50, p.1260-1276, 2009.

MENCUCCINI, M.; MAMBELLI, S.; COMSTOCK J. Stomatal responsiveness to leaf water status in common bean (Phaseolus vulgaris L.) is a function of time of day. Plant, Cell and Environment, v.23, p.1109-1118, 2000.

MORAN, N. Rhythmic leaf movements: physiological and molecular aspects. In: MANCUSO, S.; SHABALA, S. (Ed.). Rhythms in plants: phenomenology, mechanisms, and adaptive significance. Berlin: Springer-Verlag, 2007. p.3-38.

OYA, T.; NEPOMUCENO, A.L.; NEUMAIER, N.; FARIAS, J.R.B.; TOBITA, S.; ITO, O. Drought tolerance characteristics of the Brazilian soybean cultivars - evaluation and characterization of drought tolerance among Brazilian soybean cultivars in the field. Plant Production Science, v.7, p. 129-137, 2004.

PIRES, J.L.F.; COSTA, J.A.; RAMBO, L.; FERREIRA, F.G. Métodos para a estimativa do potencial de rendimento da soja durante a ontogenia. Pesquisa Agropecuária Brasileira, v.40, p.337-344, 2005.

PRICHARD, J.M.; FORSETH, I.N. Rapid leaf movement, microclimate, and water relations of two temperate legumes in three contrasting habitats. American Journal of Botany, v.75, p.1201-1211, 1988.

REY, H.; DAUZAT, J.; CHENU, K.; BARCZI, J-F; DOSIO, G. A.; LECOEUR, J. Using a 3-D virtual sunflower to simulate light capture at organ, plant and plot levels: contribution of organ interception, impact of heliotropism and analysis of genotypic differences. Annals of Botany, v.101, p.1139-1151, 2008.

ROSA, L.M.; DILLENBURG, L.R.; FORSETH, I.N. Responses of soybean leaf angle, photosynthesis and stomatal conductance to leaf and soil water potential. Annals of Botany, v.67, p.51-58, 1991.

ROSA, L.M.; FORSETH, I.N. Diurnal patterns of soybean leaf inclination angles and azimuthal orientation under different levels of ultraviolet-B radiation. Agricultural and Forest Meteorology, v.78, p.107-119, 1996.

ROSS, J.; ROSS, V.; KOPPEL, A. Estimation of leaf area and its vertical distribution during growth period. Agricultural and Forest Meteorology, v.101, p.237-246, 2000.

SANTOS, H.G. dos; JACOMINE, P.K.T.; ANJOS, L.H.C. dos; OLIVEIRA, V.A. de; OLIVEIRA, J.B. de; COELHO, M.R.; LUMBRERAS, J.F.; CUNHA, T.J.F. (Ed.). Sistema brasileiro de classificação de solos. 2.ed. Embrapa Solos: Rio de Janeiro, 2006. 306p.

THORNTHWAITE, C.W.; MATHER, J.R. The water balance. New Jersey: Drexel Institute of Technology, 1955. 104p.

VENABLES, W.N.; SMITH, D.M. An introduction to R.: notes on R: a programming environment for data analysis and graphics. Version 2.11.0. Available at: <http://cran.r-project. org/doc/manuals/ R-intro.pdf $>$. Accessed on: 21 July 2010.

WANG, C.; ISODA, A.; LI, Z.; WANG, P. Transpiration and leaf movement of cotton cultivars grown in the field under arid conditions. Plant Production Science, v.7, p.266-270, 2004.

WRIGHT, A.D.; BERLINER, P.R. The Use of soybean leaflet angle data for irrigation scheduling. Irrigation Science, v.7, p.245-248, 1986.

ZHENG, B.; SHI, L.; MA, Y.; DENG, Q.; LI, B.; GUO, Y. Comparison of architecture among different cultivars of hybrid rice using a spatial light model based on 3-D digitising. Functional Plant Biology, v.35, p.900-910, 2008.

Received on February 20, 2010 and accepted on June 4, 2010

Pesq. agropec. bras., Brasília, v.45, n.7, p.661-670, jul. 2010 